\title{
MYOPATHY ASSOCIATED WITH PIGMENTARY DEGENE- RATION OF THE RETINA AND HIGH PROTEIN CONTENT OF CEREBROSPINAL FLUID
}

\author{
José ANTONIO LeVy* \\ Milberto SCAFF * \\ Ana Maria C. Tsanaclis ** \\ VANDERLEI GaRCIA RODRIGUES *** \\ EdGaRD Silva LuSvarghI **
}

Harenko and Lapallainen ${ }^{*}$ (1962) reported a case of chronic progressive ophtalmoplegia with pigmentary degeneration of the retina, also referring 5 similar reports. Assis ${ }^{1}$ (1967) published the case of a 16-year-old female patient with progressive ophthalmoplegia, which began with palpebral ptosis and pigmentary degeneration of the retina, spreading to the macular regions; biopsy of the left superior rectus muscle showed a dystrophic process, i.e., a myopathy. Olson ${ }^{6}$ reported 7 cases of progressive ophthalmoplegia (patients' ages varied between 11 and 47 years, the period of time from the onset of the disease varying between 3 and 12 years) in which the biopsy of clinically normal limb muscles showed alterations confirming the existence of a myopathy. A biopsy revealing myopathy and the external ophtalmoplegia were common in all these patients. Three of them displayed pigmentary retinosis; three had a slight motor deficit in the limb girdle muscles; four had electroencephalographic abnormalities; in 5 of the cases which underwent a cerebrospinal fluid examination, a high protein content was encountered; in four cases the muscle biopsy showed alterations which suggested a lesion of the peripheral motor nerve; none of the cases suggested progressive muscular dystrophy with serious motor deficit in the limb girdle muscles. Kearn, quoted by Engel ${ }^{2}$, reported the case of a myopathic patient with external ophtalmoplegia associated with cardiomyopathy and pigmentary degeneration of the retina. Murakami and Mukano $^{5}$ reported the case of a 25-year-old patient suffering from external ophtalmoplegia, dysphonia, dysphagia, and muscle atrophies in the face, neck and limb girdle regions; this condition which appeared when the patient was 11 years old, developed slowly and was accompanied by a degeneration of the retina. The electromyographic examination showed myopathic characteristics. No similar reports were encountered in present day literature.

A study was made of two Brazilian brothers of Japanese descent, presenting a clinical and histopathological picture of progressive muscular dys-

Department of Neurology, Hospital das Clinicas, University of São Paulo, Brazil.

* Assistant Professor; * Resident. 
trophy associated with serious pigmentary degeneration of the retina and high protein content in the cerebrospinal fluid.

The following paragraphs contain a description of the case reports under discussion.

\section{CASE REPORTS}

CASE 1 - S.T., a 27-year-old male, was admitted to the Neurologic Department, on May 10, 1972. The patient complained of 8 years of progressive weakness in the lower limbs, starting with difficulty in climbing stairs. Two years later the weakness reached the upper limbs. From the age of 12 he suffered from progressive failure of vision in the dark. F'amily history - The patient had 7 siblings; one of his brothers had a similar disease and is described under Case 2. There was no consanguinity between the parents. Clinical examinatio: normal. Neurological examination - Hypotonia and motor deficit in the four limbs, predominantly proximal; myopathic gait; inability to climb stairs; bilateral facial paresis (fig. 1); right side palato pharyngeal paresis; left vocal cord paralysis; normal motor coordination; generalized absence of deep reflexes; normal plantar reflexes, normal deep and superficial sensibility. Fundoscopic examination (Fig.2) - Optic nerve atrophy and almost complete degeneration of the retina, with the exception of sporadic normal areas of varying shapes and sizes, in addition to peripheric pigmentary agglomerations. Under retinian vessels (very thin arteries) pigmentary epithellium appeared as a dark blue mosaic pattern; in this epithellium the choroid vessels were seen thicker and deeper. Where both retina and choroid elements were absent, the white sclerotic was apparent.

Laboratory tests - Normal results were obtained from urinalysis, blood sugar test, blood cell count, blood urea, serum protein electrophoresis, serum glutamic oxalacetic and glutamic pyruvic transaminases, serum cholesterol and serological reactions for syphilis. Cerebrospinal fluid (suboccipital puncture): protein content of $70 \mathrm{mg} / 100 \mathrm{ml}$; protein electrophoresis (Grassmann and Hannig technique) ${ }^{3}$ evidenced high gammaglobulin fraction value, accounting for $19 \%$ of the total protein content.

CASE 2 - I.T., a 19-year-old male was admitted to the Neurologic Department on May 10, 1972. The patient complained of 3 years of progressive weakness of both upper and lower limbs, which made climbing stairs and raising his arms impossible; swallowing had also become difficult, and since the age of 12 he had become nearsighted, with progressive failure of vision in the dark, and head movements caused an increasing dizziness. Family history - See case 1. Clinical Examination - normal. Neurological examination (Fig. 1) - Hypotonia and motor deficit in the four limbs, mainly proximal; myophatic gait; inability to climb stairs; bilateral facial paresis; bilateral palato pharyngeal paresis; normal motor coordination; generalized abscence of deep reflexes; normal plantar reflexes; normal deep and superficial sensibility. Examination of the $8^{\text {th }}$ cranial nerve showed bilateral impairment of the fast component of nystagmus (suggesting a lesion or dysfunction of the reticular formation). Fundoscopic examination was similar to case 1 (Fig. 2). Laboratory tests: normal results were obtained from urinalysis, blood sugar test, blood cell count, blood urea, serum protein electrophoresis, glutamic oxalacetic and glutamic pyruvic transaminases, serum cholesterol and serological reactions for syphilis. Cerebrospinal fluid (suboccipital puncture): xanthochromia; protein content of $68 \mathrm{mg} / 100 \mathrm{ml}$; protein electrophoresis (Grassmann and Hanning technique) ${ }^{3}$ showed high gammaglobulin fraction value, accounting for $18 \%$ of the total protein content.

The electroencephalographic examination was normal in case 1 , but in case 2 showed a bilateral temporal paroxistic abnormality (high voltage 4 to $10 \mathrm{c} / \mathrm{seg}$. wave groups). 


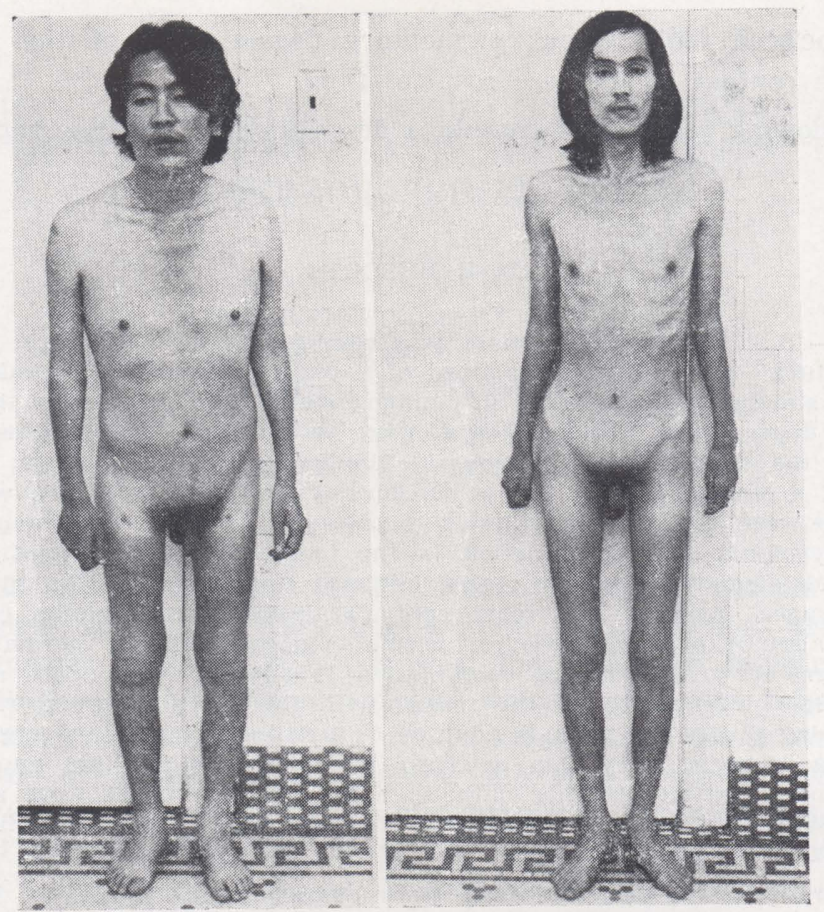

Fig. 1 - Cases 1 and 2 (S.T. at left, and I.T. at right). Photographs showing atrophy of the upper and lower limb girdle muscles.
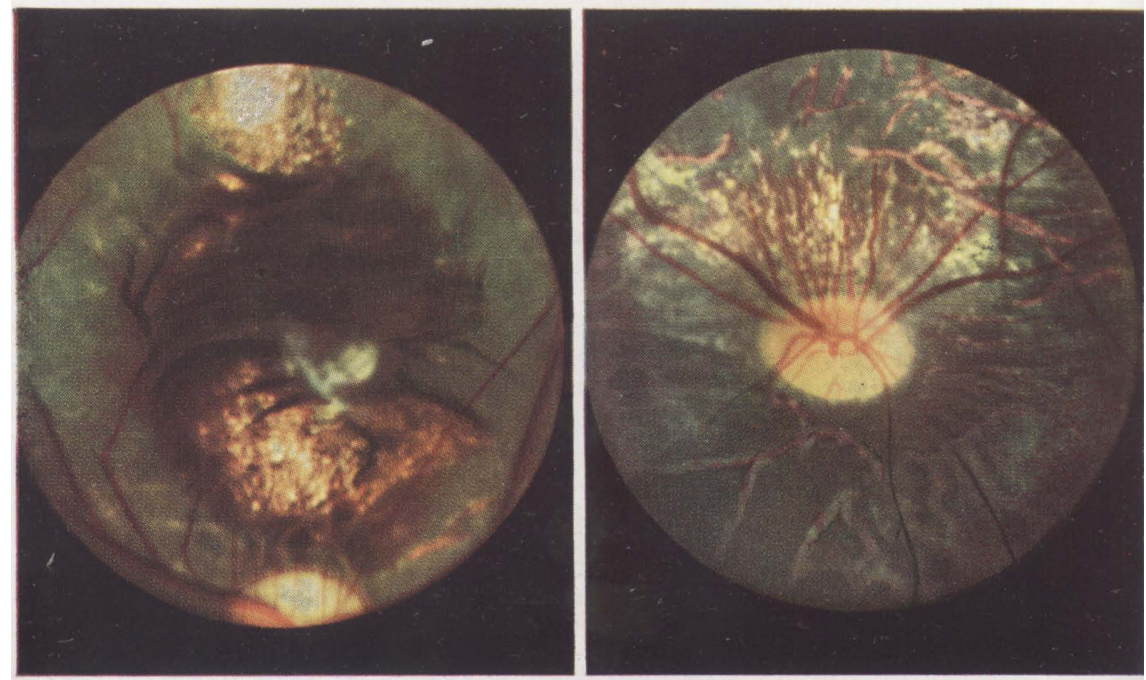

Fig. 2 - Fundoscopic aspects showing optic nerve atrophy and almost complete degeneration of the retina in case 1 (left) and case 2 (right). 

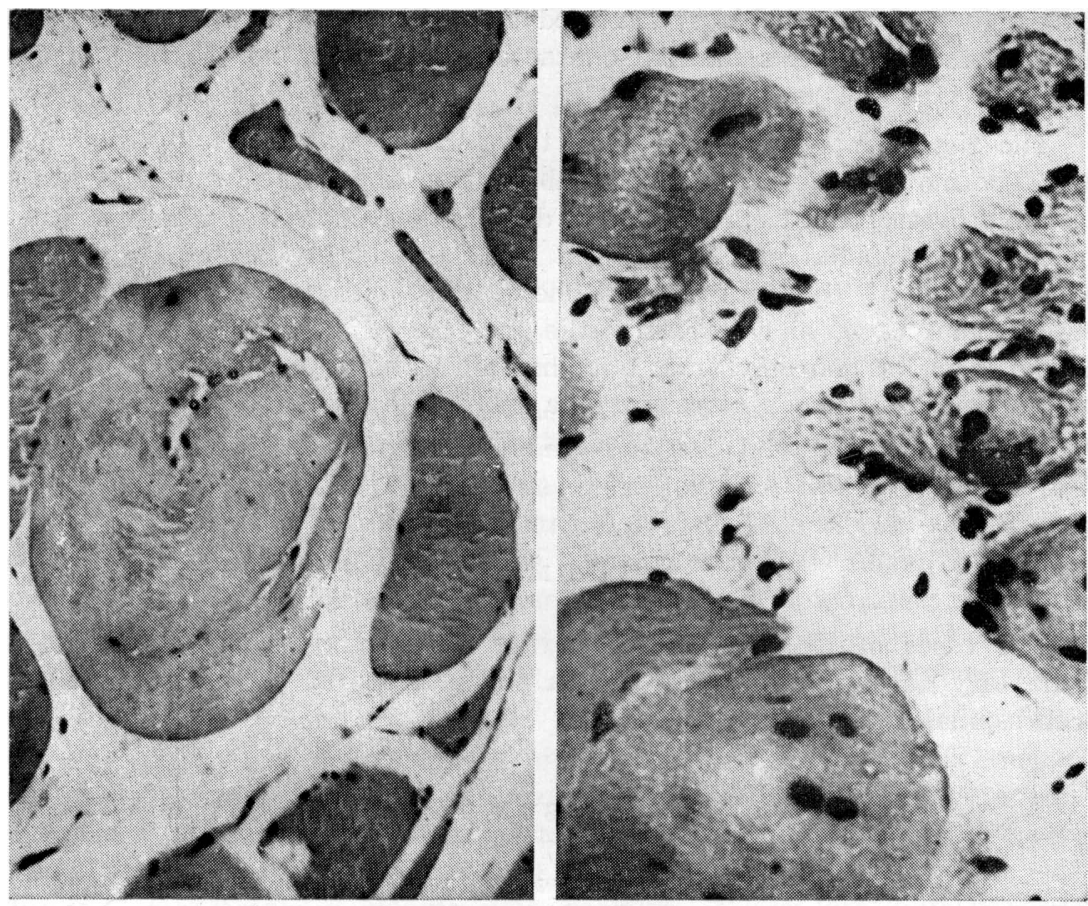

Fig. 3 - Muscle biopsy: degenerated muscle fibres of various sizes in case 1 (left), and case 2 (right).

Electromyographic examination - of the face and limb muscles of both patients, showed: at rest, fibrilations in most of the muscles examined; during contraction, decrease in the duration and amplitude of action potentials with a paradoxical pattern of interference (DISA): Electromyographic apparatus, Model 14 a 20). Muscle biopsies in both patients revealed fibres of various sizes, some rounded and some degenerated with loss of striation, in addition to prollferation of connective tissue (Fig. 3). Fundoscopic examination of both parents and five sibllings was normal. A sixt (21 year-old male) showed a infrapapillar pigmentary alteration of the choroid, with no definite characteristics.

\section{I S CUS S I O N}

The association of ocular myopathy and pigmentary degeneration of the retina has been reported by several authors $1,2,4,6$, some of whom also mentioned a deficit of the limb girdle muscle ${ }^{5,6}$ and in some cases high protein content in the cerebrospinal fluid. Reviewing literature no reference was found to an association of pigmentary retinosis, high protein content in the cerebrospinal fluid and a serious myopathic impairment mainly in the limb girdle muscles. In the present cases, even though a lesion of the nervous system was demonstrated by the examination of the cerebrospinal fluid, both electro- 
myography and muscle biopsy revealed the existence of a primary myopathy. Though this disease has familial characteristics, it was not possible to determine the type of transmission.

The first symptom described by the patients was difficult vision in the dark. The motor deficit, though resembling the limb girdle form of progressive muscular dystrophy at its onset and distribution, showed a difference in tire impairment of facial and pharyngeal muscles and in the total abscence of deep reflexes of the four limbs. The protein citologic dissociation in the cerebrospinal fluid, and especially the increase of gammaglobulin, suggested the existence of neuromyositis, but the family history, the retinal alteration and normality of the glutamicpyruvic transaminases led to the rejection of this diagnosis. Only more detailed studies and new cases would enable a better understanding of this disease.

\section{S U M M A R Y}

The cases of two brothers suffering from a myopathy associated with pigmentary degeneration of the retina and increase of protein content of the cerebrospinal fluid are reported.

\section{R E S U M O}

Miopatia associada a degeneração pigmentar da retina e hiperproteinorraquia.

Foram estudados dois pacientes, filhos de pais não consangüíneos, com quadro miopático, iniciado na segunda década da vida, com predomínio na musculatura das cinturas e da face. Em ambos os casos havia degeneração pigmentar da retina e aumento da taxa protéica no líquido cefalorraqueano.

REFERENCIAS

1. ASSIS, G. — Chronic external progressive ophtalmoplegia. Arch. Soc. Amer. Ophtal. Optom. 6:13, 1967.

2. ENGEL, W.K. - Classification of neuromuscular disorders. In D. Bergsman Birth Defects, part VII Muscles. Williams \& Wilkins, Baltimore, 1971.

3. GRASSMANN, W. \& HANNIG, H. - Paper electrophoresis. In Cramer - Papper Chromatography. Macmillan, New York, 1954. pp. 39-43.

4. HARENKO, A. \& LAPALLAINEN, A. - Chronic progressive ophtalmoplegia with pigmentary degeneration of the retina. Nord. Med. 67:24, 1962.

5. MURAKAMI, S. \& MUKANO, K. - A case of descending ocular myopathy associated with retinal degeneration. Clin. Neurol. (Tokio) 11:301, 1971.

6. OSLON, W. - Oculocraniosomatic neuromuscular disease with "reggedred" fibers. Histochemical and ultrastructural changes in limbes muscle of a group of patients with idiopathic progressive external ophtalmoplegia. Arch. Neurol. (Chicago) 26:193, 1972 . 